(RESEARCH ARTICLE)

\title{
Vitamin D status and its influence on pregnancy outcomes amongst pregnant women in southeastern Nigeria
}

Adinma Joseph Ifeanyi Brian-D 1,4,*, Ahaneku Joseph Eberendu ${ }^{2}$, Adinma Echendu Dolly ${ }^{3}$, Ugboaja Joseph Odilichukwu ${ }^{1}$, Egeonu Richard Obinwanne ${ }^{1}$ and Edet Mark Matthew ${ }^{4}$

${ }^{1}$ Department of Obstetrics and Gynecology, Nnamdi Azikiwe University and Teaching Hospital (NAUTH), Nnewi, Nigeria.

${ }^{2}$ Department of chemical pathology, Nnamdi Azikiwe University, Nnewi, Nigeria.

${ }^{3}$ Department of community medicine, Nnamdi Azikiwe University and Teaching Hospital, Nnewi, Nigeria.

${ }^{4}$ Centre for health and allied legal and demographical development research and training (CHALADDRAT), Nnamdi

Azikiwe University, Awka, Nigeria.

Publication history: Received on 14 July 2020; revised on 29July 2020; accepted on 07 August 2020

Article DOI: https://doi.org/10.30574/wjarr.2020.7.2.0264

\begin{abstract}
This is a prospective cross-sectional study involving 256 consecutive consenting parturient women in southeastern Nigeria. The study aimed to determine the vitamin D levels of the pregnant women together with its influence on pregnancy outcomes. It involved assay of vitamin D levels from blood samples of the women using High Pressure Liquid Chromatography (HPLC).Vitamin D levels were analyzed in respect of the women's biodata and pregnancy outcome variables using SPSS. Data comparison was made using chi-square test and student t-test with p-values of $<0.05$ at $95 \%$ confidence interval considered as significant. Of the 256 pregnant women studied, 36(14.1\%) had vitamin D deficiency (VDD). Mean serum vitamin D significantly decreased with increasing parity and increasing gestational age up to term (37-42 weeks). There was progressive increase in number of women (normal and vitamin D-deficient) for labour onset between $37^{\text {th }}$ and 42 nd weeks. Vitamin D levels did not influence type or mode of delivery. No trend occurred between vitamin D and both antenatal and labour complications and no relationship occurred between serum vitamin D and fetal birth weight; although number of women with VDD increased with increasing placental weight. The prevalence of VDD in pregnant women in this study (14.1\%), is low. There is also no associated deleterious pregnancy outcome to justify routine antenatal vitamin D supplementation, as suggested elsewhere. A larger population and multi-centered study may perhaps elucidate further the influence of vitamin D on pregnancy outcome amongst the people in this study area.
\end{abstract}

Keywords: Vitamin D; Maternal fetal outcome; pregnant women in southeast Nigeria.

\section{Introduction}

Vitamin D deficiency (VDD) in pregnancy is a common problem globally, but is more prevalent among pregnant women in the developing countries [1]. Vitamin D is obtained in the body either through dietary sources or from cutaneous synthesis which constitutes its major source in humans [2, 3]. Ultraviolet B radiation from sunlight causes photolytic non-enzymatic conversion of the 7-dehydroxycholesterol in the skin to previtamin D3 which is ultimately converted to its isomer, vitamin D3. In societies where people have limited exposure to sunlight, dietary supplementation is therefore extremely important. In the liver, vitamin D3 is metabolized to 25-hydroxyvitamin D (250HD) through the action of 25hydroxylase enzyme. This is further converted by $1 \alpha$-hydroxylase enzyme to 1,25 -dihydroxyvitamin $\mathrm{D}(1,25$ [OH] $2 \mathrm{D})$, which is an active form of vitamin D [4]. The serum level of vitamin D is determined by its circulating form, 25hydroxyvitamin D (25(OH) D) [5].

Vitamin D status is considered adequate when 25(OH) D levels are above $50 \mathrm{nmol} / \mathrm{l}$ as defined by the Institute of Medicine. A level between 30 and $50 \mathrm{nmol} / \mathrm{L}$ is considered insufficient, and level less than $30 \mathrm{nmol} / \mathrm{L}$, deficient [6].

\footnotetext{
* Corresponding author: Adinma Joseph Ifeanyi Brian-D
} 
Similarly, the fetal level of vitamin D correlates directly with the maternal level, hence, maternal insufficiency translates to fetal/neonatal insufficiency [7].

In the past decade, maternal vitamin D insufficiency and deficiency have been considered as a public health issue. This is because insufficiency and deficiency are linked to adverse pregnancy outcome for both the mother and the child. These complications include gestational diabetes mellitus, preeclampsia, infections, increase caesarean sections rate, fetal growth restrictions, and poor fetal and infant bone mineralization $[8,9]$. Low levels of vitamin D in pregnancy has been reported to be caused by poor exposure to sunlight needed to synthesize vitamin D3 (cholecalciferol) in the skin, dark skin colour as well as low dietary intake to meet the increase demands of pregnancy [10]. Due to their skin colour, black women are generally considered to have lower serum vitamin D levels and hence, have higher chances of vitamin D insufficiency when compared to white women [11]. This may be due to increased melanin in the skin of blacks, which invariably decreases the amount of sunlight that get to the skin for production of vitamin D [12].

Risk factors have been attributed to vitamin D deficiency and they include ethnicity [13], extensive skin coverage [14], and liberal use of sun protection. Others are obesity, low dietary level, smoking and seasonal variations [15] as seen in the temperate regions.

There is conflicting evidence on the impact of hypovitaminosis D on the development of pregnancy complications in Nigeria $[16,17]$. For example, a study in Maiduguri, northern part of the Nigeria by Sanchez et al [18] did not show any correlation between serum vitamin D levels and pregnancy complications. Similarly, Gbadegesin et al in Lagos, Nigeria in a study involving 461 pregnant women did not show any difference between the groups regarding complications during pregnancy, including preeclampsia and rate of caesarean sections [19].

There is a dearth of studies evaluating the serum level of Vitamin D in pregnancy and its influence on pregnancy outcome in southeastern Nigeria. This study has been undertaken among pregnant women in Anambra state of Southeastern Nigeria, to determine their serum vitamin D status - whether normal or deficient, and the influence of certain bio characteristics - maternal age, gestational age and parity on their vitamin D levels. It also investigates the relationship if any between the vitamin D status of the pregnant women and gestational age at labour; antenatal and labour complications; together with pregnancy and neonatal outcomes. The result from this study is expected to not only provide baseline information on relationships between vitamin $D$ and pregnancy but may also inform policy guide on the need or not to administer routine vitamin D supplementation for certain categories of pregnant women in the study area.

\section{Study background}

This study was conducted in Anambra state, one of the five states of South-eastern geopolitical zones of Nigeria, and of a predominantly Igbo-speaking population. The Igbos comprise one of the three major ethnic groups in Nigeria, the others being the Yorubas of the west and the Hausas of Northern Nigeria. These three ethnic groups have major cultural and religious differences. Anambra state, one of the 36 states of the Nigerian federation comprises of approximately five million people that are predominantly traders and of Christian religious denomination. Nnamdi Azikiwe University Teaching Hospital and Holy Rosary Maternity Hospital, where the study has been conducted are respectively a tertiary, and secondary voluntary agency hospital with a wide patient catchment that covers up to six (6) states of Nigeria, and a mix of antenatal patients that cut across the various socio-economic strata and rural-urban domicile.

\section{Subject and methods}

This was a prospective, cross-sectional study, conducted on 256 consecutive consenting parturient women at two locations in Anambra state of south eastern Nigeria - Nnamdi Azikiwe University Teaching hospital Nnewi and Holy Rosary Maternity hospital Waterside Onitsha, to determine the vitamin D status of the pregnant women, and its influence on pregnancy outcome.

Ethical approval for this study was obtained from the ethical committees of the study institutions. Appropriate participatory consent was elicited and obtained from the parturient women following painstaking explanation and counselling on the nature of the study.

Relevant meetings were held between the study investigators and the head of department of obstetrics and gynaecology of the study institutions together with the resident doctors, the nurses and pathologists involved in the study to facilitate a clear understanding and correct conduct of the exercise. 
Blood samples were taken from the women during labour. Serum obtained from each maternal blood sample was labelled and stored at -800 centigrade, and ultimately assayed for 25-hydroxyvitamin D3 using High Pressure Liquid Chromatography (HPLC). A proforma was completed for each subject and elicited information with respect to the biocharacteristics of the patient - age of the mother, her parity, and gestational age. Other documented information include the antenatal and labour complications, pregnancy outcome in terms of type of labour and mode of delivery, and neonatal outcomes in respect of fetal birth weight, fetal status and placental weight. Data obtained from the proforma and study blood sample were coded and keyed into the computer for analysis. Data analysis was performed using SPSS version 23. The bio-characteristics in the proforma were cross-tabulated with the mean vitamin D levels of the subjects, while the pregnancy and neonatal outcome variables were cross-tabulated with respect to normal and deficient vitamin D levels. Comparison of variables was performed using chi-square test and t-test where necessary. P-values of less than 0.05 at $95 \%$ confidence interval were considered to be statistically significant.

\section{Results}

Figure 1 shows the distribution by normal and deficient levels of Vitamin D for the pregnant women. Deficient levels of Vitamin D occurred in 36(14.1\%) of the pregnant women while $220(85.9 \%)$ of the women had normal serum vitamin D level. The mean vitamin D level for women with deficiency is $29.49 \pm 1.26 \mathrm{ng} / \mathrm{ml}$, while the mean vitamin $\mathrm{D}$ for the women with normal serum vitamin D level is $48.04 \pm 10.23 \mathrm{ng} / \mathrm{ml}$. The difference was statistically significant $(\mathrm{p}=0.000)$.

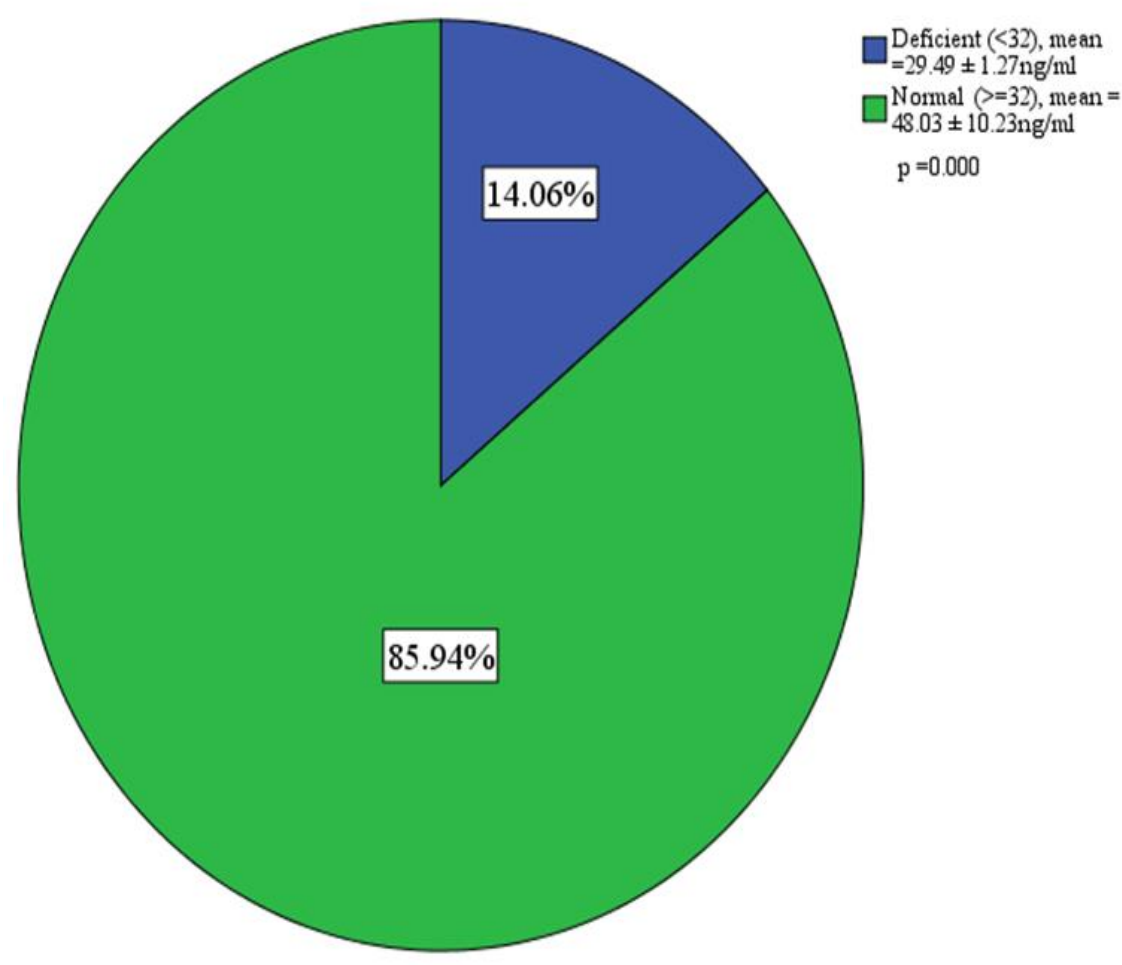

Figure 1 Distribution by normal and deficient level of Vitamin D of the pregnant women

Mean vitamin D levels was highest amongst women in 35 to 39 years age range $(49.82 \mathrm{ng} / \mathrm{ml})$ and lowest among women aged 40 years and above $(39.46 \mathrm{ng} / \mathrm{ml})$. There was a significant decrease in mean serum vitamin D level with increasing parity, being highest in the primigravidae (para 0) $-47.04 \mathrm{ng} / \mathrm{ml}$, and lowest amongst the grandmultipara (para 5 and above) $-34.02 \mathrm{ng} / \mathrm{ml}, \mathrm{p}=0.000$. Mean vitamin D level was highest in women of gestational age $<28 \mathrm{weeks}(56.98 \mathrm{ng} / \mathrm{ml})$ but significantly decreased with increasing gestational age up to term (37th to $42 \mathrm{nd}$ weeks) - (43.17 $\mathrm{ng} / \mathrm{ml})$-table 1 . 
Adinma et al. / World Journal of Advanced Research and Reviews, 2020, 07(02), 089-098

Table 1 Distribution by the bio characteristics for mean vitamin D values of the participants $(\mathrm{N}=256)$

\begin{tabular}{lllll}
\hline Characteristics & Number & Percent & Mean Vitamin D level (ng/ml) & P-Value \\
\hline Age range & & & & \\
$20-24$ & 41 & 16.0 & 47.00 & 0.110 \\
$25-29$ & 93 & 36.3 & 43.95 & \\
$30-34$ & 89 & 34.8 & 44.84 & \\
$35-39$ & 29 & 11.3 & 49.82 & \\
40 and above & 4 & 1.6 & 39.46 & \\
Parity & & & & \\
0 & 73 & 28.5 & 47.04 & \\
$1-4$ & 175 & 68.4 & 44.81 & \\
5 and above & 8 & 3.1 & 34.02 & \\
Gestational age & & 10.5 & 51.94 & \\
$<28$ & 5 & 2.0 & 56.98 & \\
$28-36$ & 32 & 12.5 & 52.66 & \\
$37-42$ & 192 & 75.0 & 43.17 & \\
42 and above & 27 & 1000 & \\
\hline
\end{tabular}

The distribution by the gestational age at onset of labour for Vitamin D levels of the women shows that for onset of labour and gestational ages 37 to 40 weeks, the number of women with deficient vitamin D showed a steady increase. Similarly the number of women with normal vitamin D also showed a steady increase between the 37th week and 40th week of onset of labour ( $\mathrm{p}=0.104)$ - table 2 .

Table 2 Distribution by the gestational age at labour for Vitamin D status of the pregnant women

\begin{tabular}{|c|c|c|c|c|}
\hline \multirow{3}{*}{ Gestational age } & \multicolumn{3}{|l|}{ Vitamin D levels } & \multirow{3}{*}{ P-Value } \\
\hline & deficient $(<32)$ & Normal ( $>=32$ ) & & \\
\hline & $\mathrm{N}=36(\%)$ & $\mathrm{N}=220(\%)$ & & \\
\hline 36 weeks and below & $0(0.0)$ & $23(10.5)$ & 7.684 & 0.104 \\
\hline 37 weeks & $0(0.0)$ & $17(7.7)$ & & \\
\hline 38 weeks & $4(11.1)$ & $23(10.5)$ & & \\
\hline 39 weeks & $8(22.2)$ & $40(18.2)$ & & \\
\hline 40 weeks and above & $24(66.7)$ & $117(53.2)$ & & \\
\hline
\end{tabular}

Table 3 shows the distribution by the pregnancy outcome for vitamin D status of the pregnant women. No significant difference occurred in vitamin D levels with respect to the type of labour - whether spontaneous 32 (88.9\%) or induced $4(11.1 \%)$, for deficient vitamin D levels, and spontaneous 197(89.5\%); induced 23 (10.5\%), for normal vitamin D levels. Similarly, no difference occurred in mode of delivery with respect to the vitamin D levels - SVD 32(88.9\%); C/S 4(11.1\%), Assisted 0(0.0\%); Breech 0(0.0\%) for deficient vitamin D levels, and SVD 182(82.7\%); C/S 33 (15.0\%), Breech 5(2.3\%), Assisted 0(0.0\%) for normal vitamin D levels. 
Table 3 Distribution by the pregnancy outcome for vitamin D status of the pregnant women

\begin{tabular}{lllll}
\hline \multirow{2}{*}{ Characteristics } & \multicolumn{2}{l}{ Vitamin D levels } & \multicolumn{1}{c}{ P-Value } \\
\cline { 2 - 3 } & $\begin{array}{l}\text { Deficient (<32) } \\
\mathbf{N = 3 6}(\%)\end{array}$ & $\begin{array}{l}\text { Normal (>=32) } \\
\mathbf{N = 2 2 0}(\%)\end{array}$ & \\
\hline Type of labour & & & 0.186 & \\
Spontaneous & $32(88.9)$ & $197(89.5)$ & & 0.666 \\
Induced & $4(11.1)$ & $23(10.5)$ & & \\
Mode of delivery & & & \\
SVD & $32(88.9)$ & $182(82.7)$ & & \\
Assisted & $0(0.0)$ & $0(0.0)$ & & \\
Breech & $0(0.0)$ & $5(2.3)$ & & \\
C/S & $4(11.1)$ & $33(15.0)$ & & \\
\hline
\end{tabular}

Figure 2 shows the distribution by ANC, and labour complications for serum vitamin D levels of the pregnant women. There was no trend between serum vitamin D levels and the various pregnancy complications - None 32(88.9\%), malaria in pregnancy $4(11.1 \%)$, preeclampsia $0(0.0 \%)$, PROM $0(0.0 \%)$, and preterm birth $0(0.0 \%), p=0.074$.

Only 6 women had postpartum hemorrhage as the only postpartum complication amongst the pregnant women, and all had normal vitamin D levels $(2.7 \%)$.

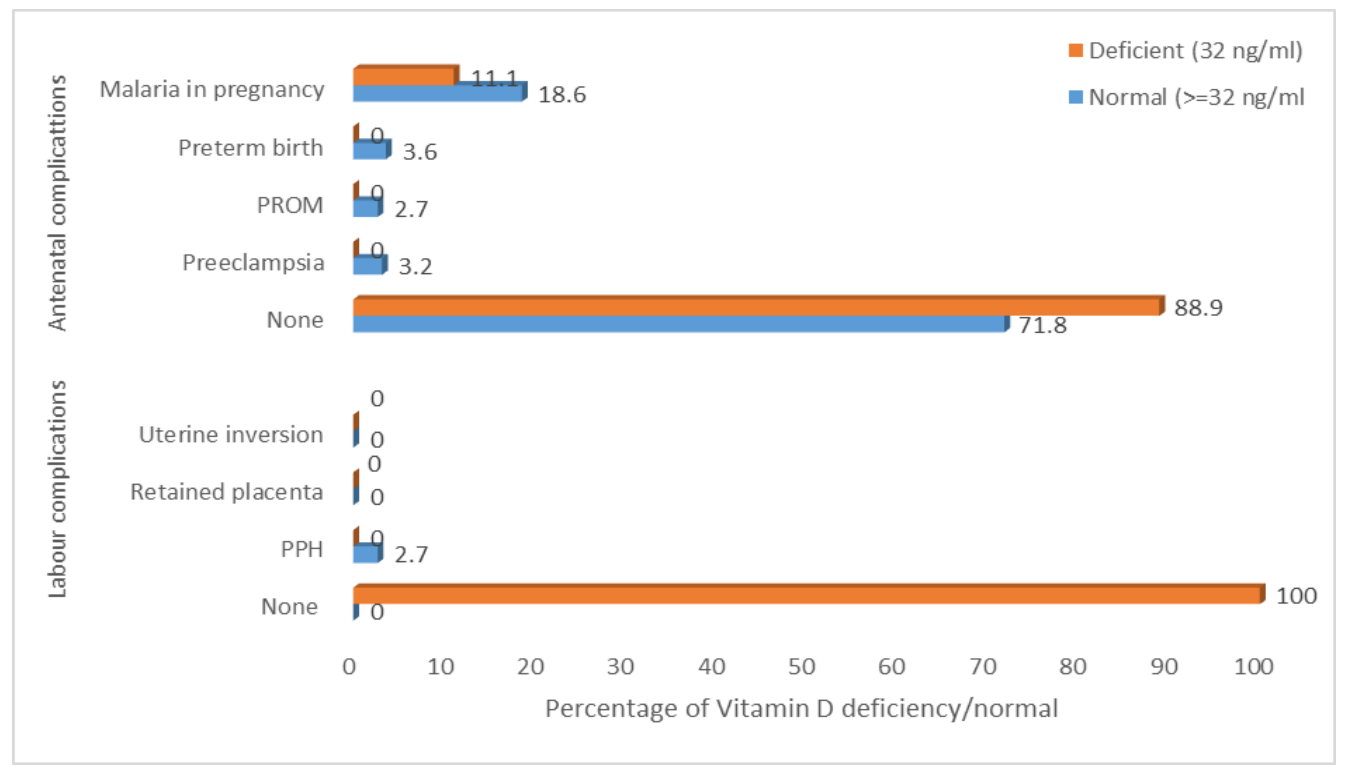

Figure 1 Distribution by ANC, and labour complications for vitamin D level of the pregnant women

Table 4 shows the distribution by neonatal outcome (fetal status, fetal birth weight, and placental weight) for vitamin D status of the pregnant women. Prematurity (FBW $<2.5 \mathrm{~kg}$ ) was not associated with deficient serum level of vitamin D. All the $8(3.6 \%)$ cases of prematurity occurred in women with normal levels of vitamin D. All the women with deficient levels of serum vitamin D had baby with mature (normal) birth weight (FBW $=2.5 \mathrm{~kg}-4.2 \mathrm{~kg}$ ). Similarly as high as 212 $(96.4 \%)$ of women with normal serum vitamin D levels also had babies with normal (mature) birth weights. There were no macrosomic (FBW $\geq 4.2 \mathrm{Kg}$ ) infants. 
All the fetuses irrespective of the maternal serum vitamin D levels (deficient or normal) were alive. Increasing placental weight was associated with more women with deficient serum level of vitamin D ( $p$-value $=0.000)$.

Table 4 Distribution by neonatal outcome (fetal status, fetal birth weight, and placental weight) for vitamin D status of the pregnant women

\begin{tabular}{|c|c|c|c|c|}
\hline \multirow[b]{2}{*}{ Characteristics } & \multicolumn{2}{|l|}{ Vitamin D levels } & \multirow[b]{2}{*}{$\chi^{2}$} & \multirow[t]{2}{*}{ P-Value } \\
\hline & $\begin{array}{l}\text { Deficient }(<32) \\
\text { N }(\%)\end{array}$ & $\begin{array}{l}\text { Normal }(\geq 32) \\
\text { N (\%) }\end{array}$ & & \\
\hline \multicolumn{5}{|l|}{ Fetal birth weight (FBW) } \\
\hline Premature $(<2.5 \mathrm{~kg})$ & $0(0.0)$ & $8(3.6)$ & 1.555 & \multirow{3}{*}{0.212} \\
\hline Mature $(2.5 \mathrm{~kg}-4.2 \mathrm{~kg})$ & $36(100)$ & $212(96.4)$ & & \\
\hline Post mature $(>4.2 \mathrm{~kg})$ & $0(0.0)$ & $0(0.0)$ & & \\
\hline \multicolumn{5}{|l|}{ Fetal status } \\
\hline Alive & $36(100)$ & $220(100)$ & & \\
\hline Still birth & $0(0.0)$ & $0(0.0)$ & & \\
\hline Perinatal death & $0(0.0)$ & $0(0.0)$ & & \\
\hline \multicolumn{5}{|l|}{ Placental Weight } \\
\hline$<500 \mathrm{gm}$ & $0(0.0)$ & $5(2.3)$ & 17.297 & 0.000 \\
\hline $500-799 \mathrm{gm}$ & $8(22.2)$ & $160(72.7)$ & & \\
\hline $800-999 \mathrm{gm}$ & $28(77.8)$ & $55(25.0)$ & & \\
\hline
\end{tabular}

\section{Discussion}

The prevalence of vitamin D deficiency in this study was 14.1\%. The finding is in line with several studies reported from different countries across the globe that show vitamin D deficiency prevalence ranging from 4-60\% [20-25]. A previous pilot study carried out on a convenient sample of 40 parturient women at Nnamdi Azikiwe University Teaching Hospital, Nnewi Nigeria showed a vitamin D deficiency level of 7.5\% [26] - almost half of our present findings. The reason for this is not very apparent. It is however likely that the small sample size and also the study site which is solely a tertiary health facility different from the study location of our present study i.e. both tertiary and secondary voluntary agency hospital, may have accounted for this difference. However, a Nigerian study by Owie et al reported prevalence rate of vitamin D in pregnancy of $4.3 \%$ which is lower than that reported in our studies. This lower prevalence reported by Owie et al [27] may be due to the lower cut off mark of $20 \mathrm{ng} / \mathrm{ml}$ that was used in the study. In this study, maternal age did not significantly influence serum vitamin D levels in pregnancy. This may be as a result of the abundant sunshine in the study area that is usually available and accessible to every pregnant woman irrespective of age. This finding agrees with the report of a systematic review by Karras et al [28], which showed no relationship between maternal age and serum level of vitamin D in pregnancy. In contrast however, to a Saudi Arabian study, Al-Daghri et al [29] had reported a higher prevalence of vitamin D deficiency amongst the younger age group of the pregnant women.

The influence of parity on serum vitamin D levels is evident from this study which demonstrates a significant decrease in mean vitamin D levels with increasing parity and this may in fact suggest increasing vitamin D deficiency with increasing parity.

Gestational age was found in this study to have an inverse relationship with maternal serum vitamin D levels. Mean serum vitamin D decreased with increasing gestational age. The reason for this is likely to be as a result of an increasing demand for vitamin $\mathrm{D}$ as the fetus grows, for the purpose of the development of the fetal bones and soft tissues. This invariably depletes maternal serum vitamin D concentration.

The onset of labour as well as the mode of delivery was not affected by the serum level of vitamin D as more than $90 \%$ of the participants carried their pregnancy to term. Some studies have shown that hypovitaminosis D affects calcium level which plays an important role in the initiation and progression of labour, and even some pregnancy complications 
such as postpartum haemorrhage (PPH) [30,31]; although this was not observed in our study. The finding in this study however agrees with the report from other studies such as that by Gbadegesin et al in Lagos Nigeria where deficient vitamin D levels showed no adverse outcome to the mother and child, including the mode of delivery [19, 32]. On the contrary Hubeish et al [33] and Scholl et al [34] reported increase in primary caesarean section in patients with low vitamin D level.

This study has not revealed any significant relationship between vitamin D deficiency and preterm birth with prematurity, since all the babies delivered by the vitamin D deficient women weighed between $2.5 \mathrm{~kg}$ and $4.2 \mathrm{kgs}$. This finding agrees with previous reports $[35,36]$.

Vitamin D plays a major role in fetal growth, development and newborns' outcomes [37]. Hence, mothers with hypovitaminosis D are likely to give birth to small for gestational age babies. This assertion has been shown by several studies [38, 39, 40]. However, Akcakus et al [37] did not find any significant association between maternal vitamin D levels and small for gestational age, just like in the present study.

Some studies have reported that vitamin D deficiency can increase the risk of preterm birth [41] and others suggested that preterm as a complication can be decreased by supplementation of vitamin D during pregnancy, in so far as vitamin D deficiency can induce preterm birth by increasing the risk from other pregnancy complications like hypertension, preeclampsia, gestational diabetes, premature rupture of membrane and bacterial vaginosis [42].

\section{Conclusion}

This study has demonstrated a vitamin D deficiency prevalence of $14.1 \%$ amongst the pregnant women of the study area. It also showed that vitamin D deficiency was associated with increasing parity as well as increasing gestational age between 28 and 42 weeks of pregnancy. This may tend to suggest a recommendation on the administration of vitamin D supplement selectively to the multiparous and grand-multiparous women or to women at term gestational age. Several studies have highlighted the place of nutritional supplements as an important component of adolescent, pre-pregnancy, and maternal nutrition in the overall promotion of pregnancy wellbeing and ultimate successful outcome for both the infant and the mother [43-46]. Incidentally the observation in this study has not impacted significantly on pregnancy outcome with respect to both the mother in terms of antenatal and labour complications, and the neonates with respect to birth weight and overall survival, enough to justify the recommendation of vitamin D supplement as may have been suggested in other studies. Perhaps a multi-centered study using a larger population of the pregnant women may further elucidate clearer, relationship between vitamin D and pregnancy outcomes in the study area.

\section{Compliance with ethical standards}

\section{Acknowledgments}

The authors acknowledge with gratitude the support of tertiary education trust fund (TETF), Nigeria for this study through its grants Number - TETF/ESS.D/6.11/NOM.RP/BAS\&BNAS (Batch 4 RP). We also acknowledge the contributions of the field researchers, midwives, laboratory scientist, doctors and heads of department of obstetrics and gynaecology of the two study facilities - Nnamdi Azikiwe University teaching hospital, Nnewi, and Holy Rosary Maternity Hospital, Onitsha, for their assistance towards the success of this work.

\section{Disclosure of conflict of interest}

The authors have no competing interests with the publication of this study.

\section{Statement of ethical approval}

Ethical approval for the present research work was obtained from the ethical committees of the two study facilities Nnamdi Azikiwe university teaching hospital, Nnewi, and Holy Rosary maternity hospital, Onitsha, Nigeria.

\section{Statement of informed consent}

Informed consent was obtained from all individual participants included in the study. 


\section{References}

[1] De Regil IM, Palacios C, Lombardo LK and Pena-Rosas JP. (2016). Vitamin D supplementation for women during pregnancy, Cochrane Data base Syst Rev, 14, CD008873.

[2] Arif SA, Erwinda E, Yusrawati Y, Safarina GM and Lipoeto NI. (2019). Vitamin D deficiency status and its related risk factors during early pregnancy: a crosssectional study of pregnant Minangkabau women, Indonesia. BMC Pregnancy and Childbirth, 19(183), 1-10.

[3] Hollis BW and Wagner CL. (2017). New insight into the vit D requirements during pregnancy. Bone Res [Internet], 5, 17030.

[4] Robinson CJ, Alanis MC, Wagner CL, Hollis BW and Johnson DD. (2010). Plasma 25-hydroxyvitamin D levels in early onset severe preeclampsia. Am J Obstet Gynaecol, 203(4), 366 e361.

[5] Hollis BW and Wagner CL. (2004). Assessment of dietary Vit D requirements during pregnancy and lactation. Am J Clin Nutr, 79(5), 717-726.

[6] IOM (institute of Medicine): Dietary reference intake for calcium and Vit D. Washington, DC, (2011).

[7] Rodda CP, Benson JE, Vincent AJ, whitehead CL, Polykov A and Vollenhoven B. (2015). Maternal vit D supplementation during pregnancy prevents vit D def in the newborn. An open- label randomized controlled trial. Clin endocrinol, 83, 363-368.

[8] Javaid MK, Crozier SR, Harvey NC, Gale CR, Dennison EM, Boucher BJ, Arden NK and Godferey KM. (2006). Hospital Study on Maternal Vit D status during Pregnancy and childhood bone mass at 9 years: a longitudinal study. Lancet, 367(9504), 36-43.

[9] Weiler H, Fitzpatrick-Wong S, Veitch R, Kovasc H, Schellenberg J, McCloy U and Yuen CK. (2005). Vit D deficiency and whole-body and femur bone mass relative to weight in healthy newborns. CMAJ, 172(6), 757-761.

[10] Elham N and Somaiyh S. (2016). Effects of vit D supplementation in the reduce risk of preeclampsia in nulliparous women. Adv Biomed Res, 5, 7.

[11] Correia A, Azevdo M, Gondin F and Banderia F. (2014). Ethnic aspects of Vit D. Arq Bras Endocrinol Metabol, 58(5), 540-4.

[12] Spiro A and Butriss JL. (2014). Vitamin D: an overview of vit D status and intake in Europe. Nutr Bull, 39(4), $322-$ 50.

[13] Bodnar LM, Catov JM, Simhan HN, Hollick MF, Powers RW and Robert JM. (2007). Maternal VIT D deficiency increases the risk of preeclampsia. J Clin Endocrinol Metab, 92(9), 3517-3522.

[14] Hobbs RD, Habib Z, Alromaihi D, Idi L, Parikh N, Blocki F and Rao DS. (2009). Severe vit D deficiency in ArabAmerican women living in Dearborn, Michigan. Endocrine Pract , 15(1), 35-40.

[15] Holick MF. (2004). Sunlight and vit D for bone health and prevention of autoimmune diseases, cancer and cardiovascular diseases. Am J Clin Nutr, 80 (6suppl), 1678S-1688S.

[16] Aghajafari F, Nagulesapillai T, Ronksley PE, Tough SC, O' Beirne M and Rabi DM. (2013). Association between maternal serum 25-hydroxyvitamin D level and pregnancy and neonatal outcome: systematic review and metaanalysis of observational studies. British Medical Journal, f1169.

[17] Kolusari A, Kurdoglu M, Yildizhan R, Adali E, Edirne T and Cebi A. (2008). Catalase activity, serum trace element and heavy metal concentrations and vit A, D and E levels in preeclampsia. Journal of international Medical Research, 36, 1335-1341.

[18] Sanchez PA, Idrisa A, Bobzom DN, Airede A, Hollis BW and Liston DE. (1997). Calcium and vit D status of pregnant teenagers in Maiduri, Nigeria. Journal of the National Medical Association, 89, 805-811.

[19] Gbadegesin A, Sobande A, adedeji O, Disu E, Korede O, Dosunmu A and Shakunle A. (2016). Maternal serum Vitamin D levels and pregnancy outcome: from Lagos, Nigeria. Journal of obstetrics and Gynaecology.

[20] Harris A. (2017). Vitamin D deficiency in pregnant women at a tertiary hospital in western Sidney. Obstst Gynaecol Int J.

[21] Abbasian M, chaman R, Amiri M, ajami ME, jafari-koshki T, Rohani H, et al. (2016). Vitamin D deficiency in pregnant women and their neonates. Glob J Health Sci, 8, 54008. 
[22] Ayadi ID, naoaili EB, Talbi E, Ghdemssi A, Rached C, Bahlous A, Gammondi A, et al. (2016). Prevalence of vit D deficiency in Mothers and their newborns in Tunisian population. Int J Gynaecol Obstet, 133, 192-5.

[23] Shresth D, Budhathoki S, Pokhrel S, Sai AK, Shrestha RK,Raya GB, Shrestha R, et al. (2019). Prevalence of vitamin $\mathrm{d}$ deficiency in pregnant women and their babies in Bhaktapur, Nepal. BMC Nutr, 5, 31.

[24] Palacios C and Gonzales L.(2014). Is vitamin d deficiency a major global public health problem? J Steroid Biochem Mol Boil, 144, 138-145.

[25] Prentice A. (2008). Vit D deficiency: a global perspective. Nutr Rev, 153-164.

[26] Adinma JIB, Nwankwo MC, Ahaneku JE, Ugboaja JO, Ibe CC and Edet MM. (2019). Vitamin D Status of pregnant women and the association between vitamin D Levels and Selected Pregnancy outcomes. International Journal of Science and Research, 8(8), 1568-1571.

[27] Owie E and Afolabi BB. (2018). Vitamin D deficiency in pregnant women and newborns in Lagos, Nigeria. J. Obstst Gynaecol, 38(5), 616-621.

[28] Karras S, Paschou SA, kandaraki E, Anglnostis P, Annweiler C, Tarlatzis BC et al. (2016). Hypovitaminosis d in pregnancy in the Mediterranean region: a systematic review. European Journal of Clinical Nutrition, 1-8.

[29] Al-Daghri NM, Al-Attas OS, Al-Okail MS, Alkharfy KM, Al-Yousef MA, Nadhrah HM, et al. (2010). Severe hypovitaminosis D is widespread and more common in non-diabetics than diabtices in Saudi adults. Saudi Med J, $31,775-80$.

[30] Oguaka VN, Adinma JIB, Okafor CI, Udigwe GO, Adinma Obiajulu-ND and Edet MM. (2019). Serum calcium in primary postpartum haemorrhage. European Journal of Pharmaceutical and Medical Research, 6(10), 53-58.

[31] Adinma JIB, Oguaka VN, Okafor CI, Udigwe GO, Adinma Obiajulu-ND and Edet MM. (2019). Serum calcium levels, uterine contractility and labour in parturient Nigerian Igbo women. Br J Bio Med Res, 3(5), 1085-1093.

[32] Al-Shaikh GK, Ibrahim GH, Fayed AA and Al-Mandeel H. (2016). Impact of vit D deficiency on maternal and birth outcomes in Saudi population: a case control study. BMC Pregnancy and Child, 16, 119.

[33] Hubeish M, Al Husari H, Itani SE, El Tal R, Tamim H and Saleh SA. (2018). Maternal Vitamin D Level and Rate of Primary Cesarean Section. Journal of Clinical Gynaecology, 7(20), 43-51.

[34] Scholl TO, Chen X and Stein P. (2012). Maternal vitamin D status and delivery by cesarean. Nutrients, 4(4), 319330.

[35] Mehta S, Hunter DJ, Mugusi FM, Spiegelman D, Manji KP, Giovannucci EL, Hertzmark E, et al. (2009). Perinatal outcomes, including mother-to-child transmission of HIV, and child mortality and their association with maternal vitamin D status in Tanzania. J Infect Dis, 200(7), 1022-1030.

[36] Hossain N, Kanani FH, Ramzan S, Kausar R, Ayaz S, Khanani R and Pal L. (2014). Obstetric and neonatal outcomes of maternal vitamin D supplementation: results of an open-label, randomized controlled trial of antenatal vitamin D supplementation in Pakistani women. J Clin Endocrinol Metab, 99(7), 2448-2455.

[37] Akcakus M, Koklu E, Budak N, Kula M, Kurtoglu S and Koklu S. (2006). The relationship between birth weight, 25hydroxyvitamin D concentrations and bone mineral status in neonates. Ann Trop Paediatr, 26(4), 267-275.

[38] Leffelaar ER, Vrijkotte TG and Van Eijsden M. (2010). Maternal early pregnancy vitamin D status in relation to fetal and neonatal growth: results of the multi-ethnic Amsterdam Born Children and their development cohort. Br J Nutr, 104(1), 108-117.

[39] Bodnar LM, Catov JM, Zmuda JM, Cooper ME, Parrott MS, Roberts JM, Marazita ML, et al. (2010). Maternal serum 25-hydroxyvitamin D concentrations are associated with small-for-gestational age births in white women. J Nutr, 140(5), 999-1006.

[40] Liu NQ and Hewison M. (2012). Vitamin D, the placenta and pregnancy. Arch Biochem Biophys, 523(1), 37-47.

[41] Bodnar LM, Rouse DJ, Momirova V, Peaceman AM, Sciscione A, Spong CY, Varner MW, et al. (2013). Maternal 25hydroxyvitamin d and preterm birth in twin gestations. Obstet Gynecol, 122(1), 91-98.

[42] Davis LM, Chang SC, Mancini J, Nathanson MS, Witter FR and O'Brien KO. (2010). Vitamin D insufficiency is prevalent among pregnant African American adolescents. J Pediatr Adolesc Gynecol, 23(1), 45-52.

[43] Adinma J, Adinma E and Umeononihu 0. (2017). Nutrition policy and practice landscape on adolescent, pre pregnancy and maternal nutrition in Nigeria. J0J nurse health care, 1(2), 555-560. 
[44] Adinma JI, Umeononihu OS and Umeh MN. (2017). Adolescent and pre-pregnancy nutrition in Nigeria. Trop J obstet gynaecol, 34, 1-5.

[45] Adinma JI, umeononihu OS and Umeh MN. (2017). Maternal nutrition in Nigeria. Trop J Obstet Gynaecol, 34(2), 79-84.

[46] Adinma JIB. (2018). Adolescent, pre-pregnancy and maternal nutrition, in: The Total Woman and Her Man: Diseases, Disorders, and other conditions perculiar to women. Lagos: Mindex pubihing Company ltd, Ltd, 3, 8196.

\section{How to cite this article}

Adinma JIB, Ahaneku JE, Adinma ED, Ugboaja JO, Egeonu RO and Edet MM. (2020). Vitamin D status and its influence on pregnancy outcomes amongst pregnant women in southeastern Nigeria. World Journal of Advanced Research and Reviews, 7(2), 89-98. 